\title{
Low B cell counts as risk factor for infectious complications in systemic sclerosis after autologous hematopoietic stem cell transplantation
}

Michael Gernert ${ }^{*}$ D, Hans-Peter Tony, Eva Christina Schwaneck, Matthias Fröhlich and Marc Schmalzing

\begin{abstract}
Background: Autologous hematopoietic stem cell transplantation (aHSCT) is a treatment option for a selected group of systemic sclerosis (SSc) patients with good available evidence but can be associated with considerable morbidity and mortality. The aim of this study was to describe infectious complications and distinct immune reconstitution patterns after aHSCT and to detect risk factors in lymphocyte subsets, which are associated with an elevated rate of infections after aHSCT.

Methods: Seventeen patients with SSC were included in this single-center retrospective cohort study. Clinical and laboratory data was collected before and for 12 months after aHSCT, including immunophenotyping of peripheral whole blood by fluorescence-activated cell sorting.

Results: Cytomegalovirus (CMV) reactivations were common in CMV-lgG-positive patients (50\%) and needed treatment. Mycotic infections occurred in $17.6 \%$. One patient died (resulting in a mortality of 5.9\%) due to pneumonia with consecutive sepsis. All patients showed decreased T helper cells $\left(\mathrm{CD}^{+} / \mathrm{CD}^{+}\right)$and within the $\mathrm{B}$ cell compartment decreased post-switched memory B cells $\left(\mathrm{CD} 19^{+} / \mathrm{CD} 27^{+} / \mathrm{lgD}{ }^{-}\right)$and elevated naïve B cells (CD19 $/$ $\mathrm{CD}_{27^{-}} / \mathrm{lgD}^{+}$) until 12 months after aHSCT. Patients who developed infections had significantly lower B cells before aHSCT than patients who did not develop infections.

Conclusion: After aHSCT, monitoring for infectious complications, especially for CMV reactivations, is crucial as the reconstitution of the immune system takes longer than 12 months. Low peripheral B cells might be a risk factor for an elevated infection rate.
\end{abstract}

Keywords: Systemic sclerosis, Autologous hematopoietic stem cell transplantation, Infectious complications, CMV reactivation, B cells

\footnotetext{
*Correspondence: gernert_m1@ukw.de

Department of Medicine II, Rheumatology and Clinical Immunology, University Hospital of Würzburg, Oberdürrbacher Str. 6, 97080 Würzburg, Germany
}

(c) The Author(s). 2020 Open Access This article is licensed under a Creative Commons Attribution 4.0 International License, which permits use, sharing, adaptation, distribution and reproduction in any medium or format, as long as you give appropriate credit to the original author(s) and the source, provide a link to the Creative Commons licence, and indicate if changes were made. The images or other third party material in this article are included in the article's Creative Commons licence, unless indicated otherwise in a credit line to the material. If material is not included in the article's Creative Commons licence and your intended use is not permitted by statutory regulation or exceeds the permitted use, you will need to obtain permission directly from the copyright holder. To view a copy of this licence, visit http://creativecommons.org/licenses/by/4.0/. The Creative Commons Public Domain Dedication waiver (http://creativecommons.org/publicdomain/zero/1.0/) applies to the data made available in this article, unless otherwise stated in a credit line to the data. 


\section{Background}

Systemic sclerosis (SSc) is a fatal autoimmune disease comprising inflammation, vasculopathy, and fibrosis. Due to pulmonary hypertension and lung fibrosis, SSc is the rheumatic disease with the highest case mortality [1]. Evidence for the treatment of SSc is rare, and disease-modifying antirheumatic drugs (DMARDs) are often not effective [2]. Methotrexate can improve skin sclerosis in early diffuse cutaneous forms of SSc [3] and is therefore mentioned in the European League against Rheumatism (EULAR) recommendations [4]. Mycophenolate mofetil [5], cyclophosphamide [6], and rituximab $[7,8]$ showed some efficacy on disease manifestation. Tocilizumab might have positive effects on lung involvement [9]. The best evidence for effective treatment of SSc is available for autologous hematopoietic stem cell transplantation (aHSCT). Three randomized controlled trials (ASSIST [10], ASTIS [11], and SCOT [12]) have shown superiority of aHSCT versus intravenous cyclophosphamide regarding skin and lung involvement, quality of life, and overall survival. Due to the intensity of the treatment, morbidity and mortality of aHSCT have to be taken into account. A higher rate of infections after aHSCT seems to correlate with $\mathrm{CD}^{+} 4^{+}$selection [13], which was performed in the three mentioned studies and also in our study.

The aim of the present study was to describe infectious complications appearing after aHSCT of SSc patients and to detect changes in leucocyte subsets during immune reconstitution, which could promote an elevated infection rate after aHSCT.

\section{Patients and methods}

\section{Patients and monitoring after aHSCT}

Seventeen patients who met the ACR/EULAR criteria [14] for SSc and had progressive disease under DMARDs and therefore underwent aHSCT in our center in the years 2009 to 2019 were included. Clinical and laboratory data were taken from the patients' electronic files (EMIL by itcms.de, Marburg, Germany and SAP SE, Walldorf, Germany). Data was collected from 4 months before until 14 months after aHSCT. All infections, which led to a medical consultation in the 14 months after aHSCT, were included. Cytomegalovirus (CMV) DNA and Epstein-Barr virus (EBV) DNA were routinely assessed with PCR for at least 100 days after aHSCT and until T helper cell counts exceeded 200/ $\mu$ l. Reactivations were defined as positive CMV or EBV DNA in the blood in patients, who had a positive CMV- or EBV-IgG before aHSCT.

\section{Myeloablative autologous hematopoietic stem cell transplantation}

Patients were treated analogous to the ASTIS trial protocol [11]: For mobilization of autologous hematopoietic stem cells, patients received $2 \mathrm{~g} / \mathrm{m}^{2}$ cyclophosphamide with at least $105 \mu \mathrm{g}$ granulocyte-colony stimulating factor daily, from day 2 after cyclophosphamide, followed by leukapheresis. CD34 ${ }^{+}$selection was performed using immunomagnetic separation (CliniMACS CD34 Complete Kit, Miltenyi Biotec, Bergisch Gladbach, Germany). Due to low stem cell numbers a CD34 $4^{+}$selection could not be done in 2 patients. As immunoablative conditioning regimen patients obtained a total of $200 \mathrm{mg} / \mathrm{kg}$ body weight (bw) cyclophosphamide on days 1-4 plus a total of $30 \mathrm{mg} / \mathrm{kg}$ bw rabbit anti-thymocyte globulin (ATG) on days 2-5. A minimum dose of $2.0 \times 10^{6}$ $\mathrm{CD}^{+} 4^{+}$autologous hematopoietic stem cells $/ \mathrm{kg}$ bw was reinfused on day 6 .

\section{Immunophenotyping}

Peripheral blood was obtained from all patients before mobilization, which was 8 weeks (median) before application of the immunoablative conditioning regimen and after (at month 1 (range 1-2), month 3 (range 3-4), month 6 (range 6-8), and month 12 (range 10-14)) aHSCT. Immunophenotyping was performed by fluorescence-activated cell sorting using a Navios cytometer (Beckman Coulter, Krefeld, Germany). Three hundred microliters of EDTA-anticoagulated whole blood was immediately processed and incubated with $10 \mu \mathrm{l}$ of each antibody for $15 \mathrm{~min}$ at room temperature. Erythrocytes were lysed with $1.33 \mathrm{ml}$ VersaLyse plus $0.66 \mathrm{ml}$ IOTest3 Fixative Solution (both Beckman Coulter, Krefeld, Germany) for $15 \mathrm{~min}$. Cells were centrifuged for $15 \mathrm{~min}$ at $300 \mathrm{RCF}$; the pellet was resuspended in $2 \mathrm{ml}$ phosphate-buffered saline plus $1 \%$ fecal calf serum, centrifuged for $15 \mathrm{~min}$ at $300 \mathrm{RCF}$; and the pellet was resuspended in $300 \mu \mathrm{l}$ phosphate-buffered saline plus $1 \%$ fecal calf serum. The following antibodies were used in different combinations: CD3-PC7, CD4-FITC, CD8-ECD, CD14-PE, CD19-PC7 and CD19-ECD, CD20-APC750, CD27-ECD, CD38-PC5.5, CD45-KromeOrange and CD45-FITC, CD56/16-PC5 (each Beckman Coulter, Krefeld, Germany), IgD-FITC, CD10-PE (each BD Biosciences, San Jose, CA), CD21-PB (Exbio, Prague, Czech Republic), and IgM-APC (BioLegend, San Diego, CA). By using forward versus sideward scatter, lymphocytes were identified. At least 3000 events within the lymphocyte gate were collected. $\mathrm{CD}^{+}$events were identified as $\mathrm{T}$ cells, $\mathrm{CD}^{+} / \mathrm{CD}^{+}$as $\mathrm{T}$ helper cells, $\mathrm{CD}^{+} /$ $\mathrm{CD}^{+}$as cytotoxic $\mathrm{T}$ cells, $\mathrm{CD} 56 / 16^{+}$as NK cells, and $\mathrm{CD}^{+} / \mathrm{CD} 56 / 16^{+}$as NKT cells. B cells were identified by $\mathrm{CD} 19^{+}$positivity. Within the $\mathrm{B}$ cell compartment, transitional $\mathrm{B}$ cells were defined as $\mathrm{CD} 38^{++} / \mathrm{CD} 10^{+} / \mathrm{IgD}^{+}$, preswitched memory B cells as $\mathrm{CD} 27^{+} / \mathrm{IgD}^{+}$, post-switched memory B cells as $\mathrm{CD}_{2} 7^{+} / \mathrm{IgD}^{-}$, double-negative (DN) B cells as $\mathrm{CD}^{2} 7^{-} / \mathrm{IgD}^{-}$, and naïve $\mathrm{B}$ cells as $\mathrm{CD}^{2} 7^{-} / \mathrm{IgD}^{+}$. 


\section{Statistical analysis}

For testing normal distribution, Shapiro-Wilk tests were performed. Most samples were not normally distributed, so medians with interquartile ranges (IQR) were indicated. To detect differences between paired groups, Wilcoxon signed-rank tests were performed and MannWhitney $U$ tests for unpaired groups. Excel (Microsoft, Redmond, Washington) was used to collect the data. To perform calculations, SPSS Statistics v 25.0 (IBM, Armonk, NY) was used. Differences were considered significant when two-tailed $P$ values were less than 0.05 .

\section{Results}

\section{Patients' characteristics}

Seventeen patients (eight female, nine male; median age 52.0 years, age range $23-64$ years) were included in the study. The median disease duration before aHSCT was 3.5 years (range 3 months to 13 years). Six patients were former smokers; one continued smoking through aHSCT. All patients had a diffuse cutaneous form, 15 patients were anti-nuclear antibody positive, eleven patients showed positivity for Scl-70 antibodies, 14 patients had pulmonary fibrosis, and 14 patients had troponin values above the upper limit of normal. Cardiac MRI was done in 13 patients; 6 of them had abnormalities. Twelve patients received a right heart catheterization with 2 of them having a pulmonal arterial hypertension. The median modified Rodnan skin score (mRSS) before aHSCT was 23.0 (range 5-44). The indication for aHSCT was in $41.2 \%$ progressive skin involvement, in $35.3 \%$ progressive lung involvement and in $23.5 \%$ both manifestations. Patients' characteristics are summarized in Table 1. At baseline, 14 of the 17 patients received an immunosuppressive medication (four patients, prednisolone; one patient, azathioprine; four patients, mycophenolate mofetil; four patients, cyclophosphamide; and one patient, tocilizumab).

\section{Aciclovir and cotrimoxazole prophylaxes are effective} Patients took aciclovir for 7.5 (IQR 5.8-11.5) months and cotrimoxazole for 9.5 (5.8-14.0) months after aHSCT. Infections with herpes simplex virus or Pneumocystis jirovecii did not occur. Prophylaxes were stopped when T helper cells increased over $200 / \mu$ l or according to the investigators decision, as six patients did not

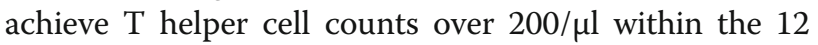
months after aHSCT.

\section{Infectious complications during the $\mathbf{1 2}$ months after aHSCT}

Eight patients did not develop any infection in the 12 months after aHSCT (47.1\%). Three patients developed mycosis (one CT-morphologic suspected mycotic pneumonia, one esophageal candidiasis, and one
Table 1 Characteristics of the study population before aHSCT

\begin{tabular}{|c|c|}
\hline Characteristics & Values \\
\hline Female, \% & 47.1 \\
\hline Age at aHSCT, median (range), years & $52.0(23-64)$ \\
\hline Disease duration before aHSCT, median (range), years & $3.5(0.3-13)$ \\
\hline Diffuse cutaneous form, \% & 100 \\
\hline mRSS, median (range) points & $23.0(5-44)$ \\
\hline Anti-nuclear antibody positivity, \% & 88.2 \\
\hline Anti-Scl-70 antibody positivity, \% & 64.7 \\
\hline Anti-Centromere antibody positivity, \% & 0 \\
\hline \multicolumn{2}{|l|}{ Smoking history, \% } \\
\hline Current & 5.9 \\
\hline Ever & 41.2 \\
\hline $\begin{array}{l}\text { Pulmonary fibrosis on thoracic computed } \\
\text { tomography, } \%\end{array}$ & 82.4 \\
\hline $\begin{array}{l}\text { FVC (\% predicted) latest value before } \\
\text { aHSCT, median (IQR) }\end{array}$ & $74.0(58.0-89.0)$ \\
\hline $\begin{array}{l}\text { DLCO (\% predicted) latest value before } \\
\text { aHSCT, median (IQR) }\end{array}$ & $44.0(29.0-59.0)$ \\
\hline Troponin positivity, \% & 82.4 \\
\hline Abnormal 24 h Holter ECG, $n(\%)$ & $1 / 15(6.7)$ \\
\hline Abnormal cardiac MRI, $n(\%)$ & $6 / 13(46.2)$ \\
\hline Right heart catheterization, done & $12 / 17$ \\
\hline Pulmonal arterial hypertension, $n(\%)$ & $2 / 12(16.7)$ \\
\hline $\begin{array}{l}\text { Mean pulmonal arterial pressure (mPAP), } \\
\text { mmHg, median (range) }\end{array}$ & $18.0(9-30)$ \\
\hline \multicolumn{2}{|l|}{ Indication for aHSCT } \\
\hline Skin, \% & 41.2 \\
\hline Lung, \% & 35.3 \\
\hline Skin and lung, \% & 23.5 \\
\hline Positive CMV-Serology, \% & 35.3 \\
\hline Positive EBV-Serology, \% & 100 \\
\hline
\end{tabular}

oral candidiasis), three patients upper respiratory tract infections, one patient an atypical pneumonia, one patient a pyelonephritis, and one patient a superinfected pancreatic pseudocyst, which required interventional drainage and prolonged antibiotic therapy. One patient died 9 months after aHSCT due to pneumonia with septic shock and lactate acidosis. The mortality rate after aHSCT of SSc patients in our study therefore accounts to $5.9 \%$. All infections that led to a medical consultation are summarized in Table 2. Not included were fevers in aplasia, as it could not be distinguished between an adverse effect of ATG or reconstitution fever or infection. Fever in aplasia occurred in 11 of 17 patients (64.7\%). 
Table 2 Infectious complications, which led to a medical consultation in the 12 months after aHSCT

\begin{tabular}{|c|c|c|c|c|}
\hline Infection (causative agent if available) & Frequency & $\begin{array}{l}\text { Occurrence after } \\
\text { aHSCT, month }\end{array}$ & Treatment & $\begin{array}{l}\text { Treatment } \\
\text { duration, weeks }\end{array}$ \\
\hline \multirow[t]{3}{*}{ CMV reactivation } & \multirow{3}{*}{$\begin{array}{l}\text { 3/17 }(17.6 \%) ; 3 / 6 \text { of CMV } \\
\text { lgG positive }(50.0 \%)\end{array}$} & 1 & Valganciclovir & 8 (prophylactic) \\
\hline & & 1 & Valganciclovir & 8 (prophylactic) \\
\hline & & 1 & Ganciclovir & 5 \\
\hline EBV reactivation & $1 / 17(5.9 \%)$ & 2 & Rituximab $2 \times 1 \mathrm{~g}$ & 2 \\
\hline Mycosis & $3 / 17(17.6 \%)$ & & & \\
\hline Nodular pneumonia & & 1 & Voriconazole & 5 \\
\hline Oral candidiasis & & 9 & Nystatin & 12 (prophylactic) \\
\hline Esophageal candidiasis & & 6 & Fluconazole & 2 \\
\hline \multirow[t]{3}{*}{ Upper respiratory tract infection } & \multirow[t]{3}{*}{$3 / 17(17.6 \%)$} & 9 & Non & na \\
\hline & & 1 & Azithromycin & 24 (prophylactic) \\
\hline & & 10 & Amoxicillin/clavulanic acid & 1 \\
\hline Atypical pneumonia & $1 / 17(5.6 \%)$ & 3 & Piperacillin/tazobactam + linezolid & 2 \\
\hline Pyelonephritis (Escherichia coli) & $1 / 17(5.9 \%)$ & 11 & Ciprofloxacin & 1 \\
\hline $\begin{array}{l}\text { Superinfected pancreatic pseudocyst } \\
\text { (Streptococcus anginosus }+ \text { Enterococcus } \\
\text { faecalis and cloacae }+ \text { Klebsiella pneumoniae) }\end{array}$ & $1 / 17(5.9 \%)$ & 3 & $\begin{array}{l}\text { Ceftriaxone + metronidazole, } \\
\text { meropenem, ciprofloxacin; } \\
\text { drainage, piperacillin/tazobactam, } \\
\text { linezolid }\end{array}$ & 14 \\
\hline Lethal pneumonia with lactate acidosis & $1 / 17(5.9 \%)$ & 9 & Piperacillin/tazobactam & 1 \\
\hline
\end{tabular}

CMV cytomegalovirus, EBV Epstein-Barr virus, na not applicable

\section{CMV and EBV reactivations}

A positive CMV serology could be detected in six patients before aHSCT, and three of these patients suffered from a CMV reactivation in the first month after aHSCT. This results in a CMV reactivation rate of $50 \%$. Two of the CMV reactivations were treated orally with valganciclovir, and one patient received intravenous ganciclovir in the intensive care unit. Positive EBV serology was present in all patients before aHSCT, and one patient suffered from an EBV reactivation in month 2, resulting in an EBV reactivation rate of $5.9 \%$. This patient received rituximab, which led to disappearance of EBV DNA in the serum (Table 2).

\section{Impact of immunosuppression after aHSCT}

Administration of DMARDs due to SSc progress after aHSCT did not correlate with higher rates of infections. Six patients received prednisolone (daily dose below 10 $\mathrm{mg}$ ), six patients received methotrexate, two received hydroxychloroquine, one patient received colchicine plus anakinra, and two patients received rituximab (due to EBV reactivation or pulmonary progress, respectively). Those therapies were given to ten patients, and only two of them (one took prednisolone $5 \mathrm{mg}$ daily, the other methotrexate $15 \mathrm{mg}$ weekly + prednisolone $5 \mathrm{mg}$ daily) developed infections (one esophageal candidiasis and one upper respiratory tract infection, respectively). Immunosuppressive therapy had only a slight impact on the immune reconstitution. Only in month 1 after
aHSCT, significant differences could be detected in few leukocyte populations comparing patients taking immunosuppressive therapy (all took prednisolone in a mean dose of $6.25 \mathrm{mg}$ (range $2.5-10 \mathrm{mg}$ ); $n=8$ ) versus patients without immunosuppressive therapy $(n=9)$ : Total $\mathrm{T}$ cell percentages were $25.0(17.3-51.5) \%$ vs 58.0 (50.8-67.8)\%; total T cell numbers $161.8(90.9-514.3) / \mu \mathrm{l}$ vs $692.1(443.9-1021.7) / \mu \mathrm{l} ; \mathrm{CD}^{+} \mathrm{T}$ cell percentages 24.0 (12.8-34.8)\% vs $43.5(40.5-57.0) / \mu \mathrm{l} ; \mathrm{CD}^{+} \mathrm{T}$ cell numbers $127.9(94.5-341.2) / \mu \mathrm{l}$ vs $583.7(332.4-899.9) / \mu \mathrm{l} ; \mathrm{NK}$ cell percentages $54.5(44.5-75.5) \%$ vs $32.5(21.8-42.8) \%$.

\section{Immune reconstitution after aHSCT takes more than 12 months}

Leukocytes, neutrophils, and monocytes showed lower numbers per $\mu \mathrm{l}$ in month 12 after aHSCT compared to numbers before aHSCT. The total lymphocyte numbers in month 12 were not different from the baseline total lymphocyte numbers. Regarding the lymphocyte/monocyte ratio, a change from 1.2 (total lymphocytes 1.1 (interquartile range $0.8-1.9) \times 10^{3} / \mu \mathrm{l}$ and monocytes 0.9 $(0.5-1.1) \times 10^{3} / \mu \mathrm{l}$ ) before aHSCT towards 2.0 (total lymphocytes $1.2(0.5-1.5) \times 10^{3} / \mu \mathrm{l}$ and monocytes $0.6(0.5-$ $\left.0.9) \times 10^{3} / \mu \mathrm{l}\right)$ after aHSCT was seen. Within the $\mathrm{T}$ cell compartment, aHSCT caused long-lasting total $\mathrm{T}$ cell and $\mathrm{T}$ helper cell reductions. $\mathrm{T}$ cell percentages (within the lymphocyte gate) and absolute numbers showed a long-term decrease until month 12 after aHSCT. Also, the $\mathrm{T}$ helper cell percentages and absolute numbers were 
decreased until month 12 starting from month 1 after aHSCT. Hence, the CD4/CD8 ratio decreased until month 12 (Table 3 and graphically as additional Fig. S1).

\section{aHSCT causes a reset of the B cell compartment}

The total $\mathrm{B}$ cell percentages and numbers were increased in month 12 after aHSCT compared to baseline values. Regarding B cell subsets, in the early phase of the B cell repopulation, transitional $B$ cells were increased. Longlasting changes were seen with reduced post-switched memory B cell numbers and increased naïve B cell numbers in month 12 after aHSCT compared to values before aHSCT (Table 3 and additional Fig. S1).

\section{Low B cells before aHSCT are associated with more infections after aHSCT}

Comparing patients who developed any kind of infection after aHSCT with those who did not develop infections showed a significant difference in B cell percentages (5.7 (3.3-5.9) \% vs. $17.2(5.9-21.9) \% ; P=0.012)$ and $B$ cell numbers $(62.2(30.3-83.2) / \mu \mathrm{l}$ vs. $146.9(98.0-465.0) / \mu \mathrm{l}$; $P=0.012$ ) before aHSCT (Fig. 1). Immunosuppressive medication, in particular cyclophosphamide application or mycophenolate mofetil intake at baseline, did not cause significant differences in B cell percentages or B cell numbers.

Regarding solely virus reactivations (EBV and CMV), no differences within the lymphocyte subsets could be detected comparing patients which suffered from virus reactivations versus those who did not. No significant differences of the B cell numbers and B cell percentages between CMV serology positive and CMV serology negative patients were present.

\section{Discussion}

In this study, we describe a cohort of 17 SSc patients who underwent aHSCT and received a treatment regimen analogous to the ASTIS trial [11]. Thereby, we focused on infections occurring in the 12 months after aHSCT and described the accompanying immune reconstitution.

The immune reconstitution pattern in our cohort showed long-term decreased $\mathrm{CD}^{+} \mathrm{T}$ cells, which puts patients at risk for reactivations of herpes viruses and opportunistic infections $[15,16]$, although opportunistic infections like Pneumocystis jirovecii pneumonias are scarce after aHSCT under prophylaxis [17]. In concordance with that, in our study, CMV reactivations were relevant complications. CMV seropositive patients developed CMV viremia in 50\% and needed treatment. Determination of the CMV and also of the EBV serostatus before aHSCT therefore seems advisable to identify patients at risk for virus reactivations. This should also comprise DNA measurements after aHSCT. Other groups reported a CMV infection rate between 10 and $64 \%$ often without indicating the serostatus for CMV before aHSCT $[10,13]$. In the ASTIS trial, the CMV serostatus was determined before aHSCT and the CMV reactivation rate was amounted to $18.7 \%$ [11]. The higher CMV reactivation rate in our study might be explained by the usage of a higher total ATG amount for conditioning regimen. A CMV prophylaxis so far is commonly not done. Prophylactic valganciclovir application may be considered for patients at risk temporary after aHSCT as all reactivations occurred within the first month after aHSCT. Valganciclovir may then be switched to aciclovir as long-term intake of valganciclovir can cause cytopenias.

Prophylactic treatment with aciclovir and cotrimoxazole is standard of care after aHSCT and is effective as no patient developed herpes simplex infections or pneumonia due to Pneumocystis jirovecii in our study. It is unclear, when these prophylaxes should be stopped. Cotrimoxazole prophylaxis is usually stopped when $\mathrm{T}$ helper cells exceed 200 cells/ $\mu$ [18], but this occurs in only few patients within the first 12 months after aHSCT. Therefore, a stepwise reduction of aciclovir and cotrimoxazole seems feasible. In our cohort, aciclovir was stopped 7.5 months and cotrimoxazole 9.5 months after aHSCT.

Other infections in our cohort were within the spectrum of infections reported in larger SSc cohorts after aHSCT (the main infectious load was due to respiratory tract infections and pneumonias) with an overall infection rate between 58.8 and $75 \%$ [11, 12, 19]. In contrast to the other cohorts, we did not detect varicella zoster virus infections or reactivations.

Many patients (64.7\%) developed fever during aplasia, but a definite infection mostly could not be proven. Those episodes were not included in our study, especially since fevers due to ATG use or due to leukocyte reconstitution could not be excluded as cause of the fever.

The mortality rate in our study after aHSCT with 5.9\% is in the range of the reported studies in the first year after aHSCT. No deaths were reported in the SCOT trial [12], 6.3\% in the European society for blood and marrow transplantation (EBMT) register [19], and $10.1 \%$ in the ASTIS trial [11]. Differences might be explained by different baseline characteristics among the study populations (in the SCOT trial, no patient had cardiac involvement or pulmonal arterial hypertension [12]) and different myeloablative protocols.

DMARD therapy after aHSCT did not correlate with an increased frequency of severe infections indicating that the aHSCT per se evokes the increased infection rate especially by changing the lymphocyte subsets. Apart from lymphocytes, monocytes play a pathogenetic 


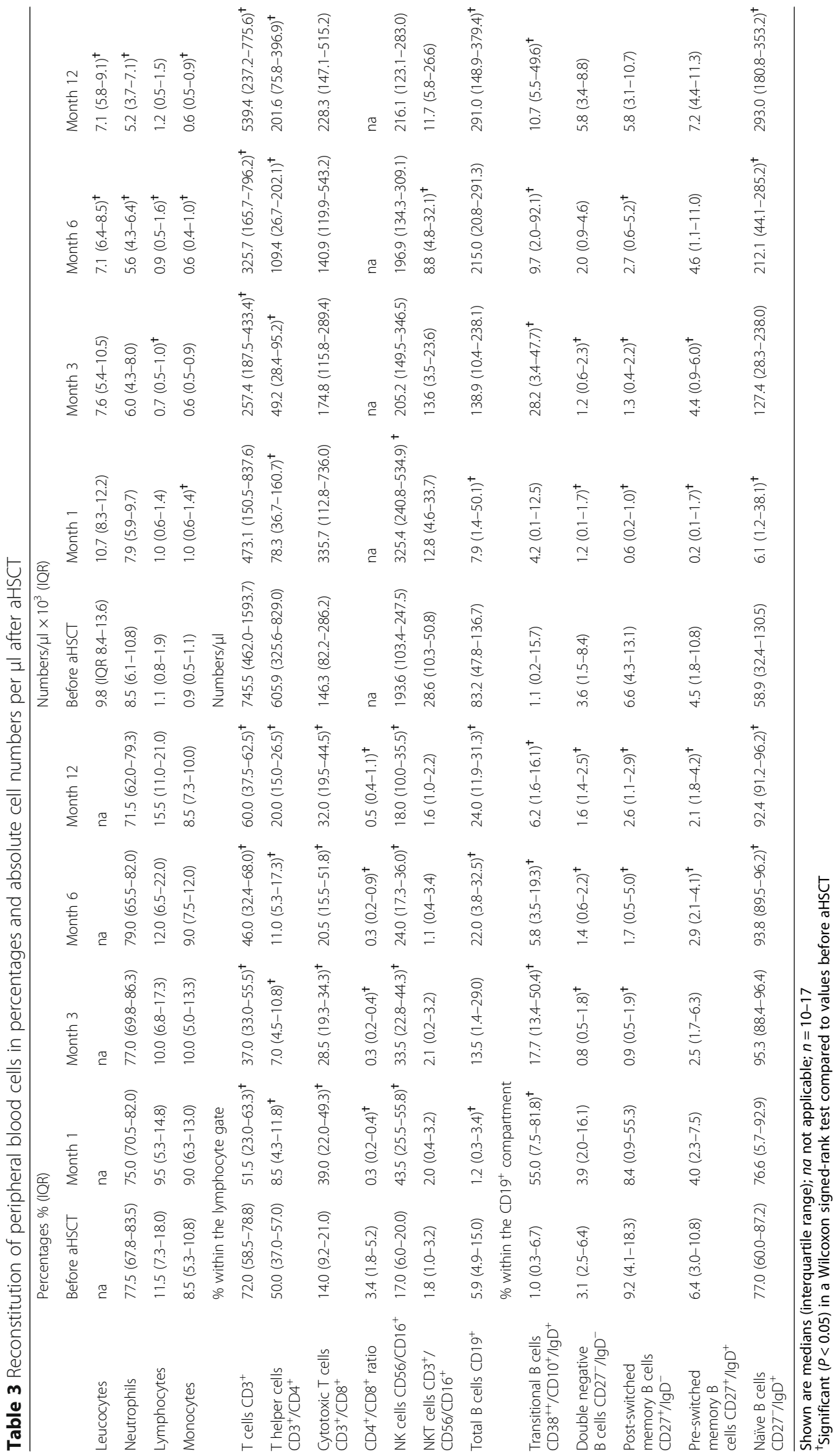



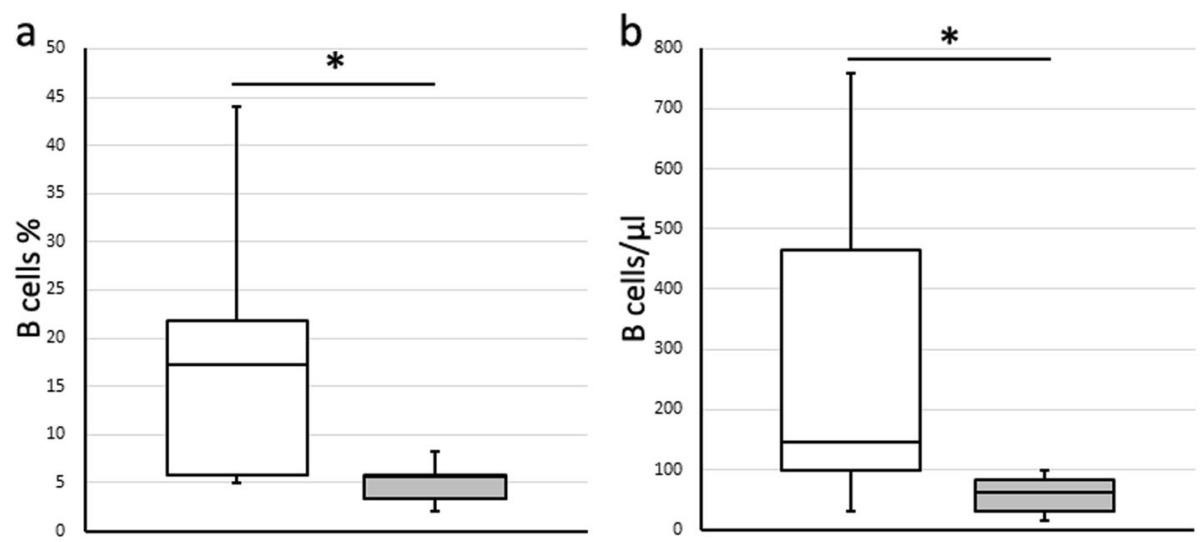

$\square$ no infection $\square$ with infection

Fig. 1 B cell percentages (a) and B cell numbers per $\mu$ l (b) of patients who did not develop infections after aHSCT (white boxes) and those who developed at least one infection (gray boxes). Shown are medians with interquartile ranges; whiskers indicate minimums and maximums; ${ }^{*} P<0.05$

role in SSc. Increased circulating monocyte numbers compared with healthy controls are reported in SSc patients $[20,21]$. We found a reduction of monocyte numbers after aHSCT and a normalization of the lymphocyte/monocyte ratio. Those changes in the lymphocyte subsets and monocytes might promote infectious complications after aHSCT but may be also responsible for the positive effects of aHSCT by resetting the immune system towards normal leukocyte distributions.

The immune reconstitution after aHSCT we present comprises increased B cell numbers, mainly due to increased naïve B cells (accompanied by decreased memory B cells) and decreased $\mathrm{CD} 4^{+} \mathrm{T}$ cells 1 year after aHSCT. This reconstitution pattern is comparable with previously reported SSc cohorts [22, 23], even if different myeloablative protocols (without ATG) were used [23], and is in concordance with the reconstitution described in patients with systemic lupus erythematodes [24] and multiple sclerosis [25]. In contrast, patients with rheumatoid arthritis showed normalized levels of B cells 1 year after aHSCT, although a similar myeloablative protocol was performed [26]. It could be speculated that the different reconstitution patterns might be influenced by different underlying autoimmune diseases. However, the long-term reduction of $\mathrm{CD} 4^{+} \mathrm{T}$ cells seems to be a common finding after aHSCT as it is also reported in malignant diseases [27, 28].

Low B cells before aHSCT were associated with more infections after aHSCT which might lead to a careful monitoring of patients who initially have low B cells. The predictive value of $\mathrm{B}$ cells has been investigated in septic patients. In a meta-analysis, sepsis non-survivors had reduced B cell numbers at the onset of sepsis compared to sepsis survivors [29].

To our knowledge, this is the first description of the potential predictive significance of B cells for outcomes after autologous hematopoietic stem cell transplantation. Confounders for baseline B cell percentages and B cell numbers, like different underlying autoimmune diseases or the influence of the pre-transplant treatment, should be evaluated in bigger cohorts in the future.

Our study is limited because of its retrospective design and the low number of patients. Two of our patients did not receive $\mathrm{CD}^{+} 4^{+}$selection of their autologous hematopoietic stem cells, which might have influenced the course of their immune reconstitution.

\section{Conclusion}

Our data suggest that it is advisable to test all SSc patients before and after aHSCT for CMV. Especially patients who have low B cells before aHSCT might be at risk for the development of infections. Our data of median lymphocyte percentages and numbers can be used as reference values after aHSCT to assess the reconstitution state in a transplanted SSc patient.

\section{Supplementary information}

Supplementary information accompanies this paper at https://doi.org/10. 1186/s13075-020-02255-3.

Additional file 1: Fig. S1. Reconstitution of peripheral blood cells. Boxplots show values at baseline, month 1, month 3, month 6 and month 12 of (a) neutrophil, lymphocyte and monocyte percentages, (b) leukocyte, neutrophil, lymphocyte and monocyte numbers/ $\mu$ l, (c) total B cell and naïve B cell percentages, (d) total B cell and naïve B cell numbers $/ \mu \mathrm{l}$, (e) transitional, double negative, post-switched memory and pre-switched memory B cell percentages, ( $f$ ) transitional, double negative, post-switched memory and pre-switched memory B cell numbers $/ \mu \mathrm{l},(\mathrm{g})$ total T cell, CD4 ${ }^{+} \mathrm{T}$ cell, CD8 ${ }^{+} \mathrm{T}$ cell, NK cell and NKT cell percentages and (h) total T cell, $C D 4^{+} T$ cell, $C D 8^{+} T$ cell, NK cell and NKT cell numbers $/ \mu$. Boxplots show medians with 25th and 75th percentiles, whiskers indicate minimums and maximums, respectively. White blots indicate cell percentages, gray blots indicate cell numbers/ $\mu$ l. * significant difference compared to baseline value, $P<0.05$. 


\section{Abbreviations}

ACR: American College of Rheumatology; aHSCT: Autologous hematopoietic stem cell transplantation; APC: Allophycocyanin; ASSIST: American Scleroderma Stem Cell versus Immune Suppression Trial; ASTIS: Autologous Stem cell Transplantation International Scleroderma trial; ATG: Antithymocyte globulin; bw: Body weight; CD: Cluster of differentiation; CMV: Cytomegalovirus; CT: Computed tomography; dcSSc: Diffuse cutaneous form of systemic sclerosis; DMARDs: Disease-modifying anti rheumatic drugs; ECD: Phycoerythrin-Texas Red; EBMT: European Society for Blood and Marrow Transplantation; EBV: Epstein-Barr virus;

EDTA: Ethylenediaminetetraacetic acid; EULAR: The European League Against Rheumatism; FITC: IgD-fluorescein isothiocyanate; Ig: Immunoglobulin; IQR: Interquartile range; mRSS: Modified Rodnan skin score; na: Not applicable; PB: Pacific Blue; PC: Phycoerythrin-cyanin; PE: Phycoerythrin; RCF: Relative centrifugal field; SCOT: Scleroderma: Cyclophosphamide or Transplantation trial; SSc: Systemic sclerosis

\section{Acknowledgements}

We thank Katharina Eckert, Silke Killinger, Brigitte Kimmel, Anette KossKinzinger, Isabelle Kuntzsch, Heide Pototzky, and Vanessa Schultz for expert technical assistance and advice. We thank Viktoria Rücker for statistical advice.

\section{Authors' contributions}

All authors were involved in drafting the article or revising it critically for important intellectual content, and all authors approved the final version to be submitted for publication. MG had full access to all of the data in the study and takes responsibility for the integrity of the data and the accuracy of the data analysis. Study conception and design: MG, MS, and H-PT. Acquisition of data: MG, MS, ECS, and MF. Analysis and interpretation of data: MG, $\mathrm{MS}$, and $\mathrm{H}-\mathrm{PT}$.

\section{Funding}

This publication was supported by the Open Access Publication Fund of the University of Würzburg. Open access funding provided by Projekt DEAL.

\section{Availability of data and materials}

The data used and/or analyzed during the current study are available from the corresponding author on reasonable request.

\section{Ethics approval and consent to participate}

This study was a retrospective cohort study, which is why approval by the local ethics committee of the University of Würzburg was not mandatory. Solely routine parameters (for a tertiary referral center) were implemented in this analysis, which is why obtaining informed consent was not necessary according to German law. All data was generated in compliance with the Declaration of Helsinki.

\section{Consent for publication}

Not applicable.

\section{Competing interests}

MG received travel grants from AbbVie, Chugai, Eli Lilly, Hexal, Janssen, Pfizer, and Roche.

H-PT received speaker's fees, travel grants, research funding, or compensation for consultancies or board memberships from AbbVie, Chugai/Roche, Eli Lilly, Gilead, Janssen, Novartis, Sandoz/Hexal, Sanofi Aventis, and Takeda (Shire).

ECS received speaker's fees, travel grants, research funding, or compensation for consultancies or board memberships from AbbVie, Chugai/Roche, Janssen-Cilag, Eli Lilly, Novartis, and Takeda (Shire).

MF received travel grants from AbbVie, Novartis, Janssen, and Eli Lilly and compensation for board memberships from AbbVie.

MS received speaker's fees, travel grants, research funding, or compensation for consultancies or board memberships from AbbVie, Actelion, BMS, Boehringer/Ingelheim, Celgene, Chugai/Roche, Eli Lilly, Genzyme, Gilead, Hexal/Sandoz, Janssen-Cilag, MSD, Novartis, Pfizer, Sanofi Pasteur, Takeda (Shire), and UCB.
Received: 15 April 2020 Accepted: 18 June 2020

Published online: 08 August 2020

\section{References}

1. Elhai M, Meune C, Avouac J, Kahan A, Allanore Y. Trends in mortality in patients with systemic sclerosis over 40 years: a systematic review and meta-analysis of cohort studies. Rheumatology (Oxford). 2012;51:1017-26.

2. Denton CP, Khanna D. Systemic sclerosis. Lancet. 2017;390:1685-99.

3. Pope JE, Bellamy N, Seibold JR, Baron M, Ellman M, Carette S, et al. A randomized, controlled trial of methotrexate versus placebo in early diffuse scleroderma. Arthritis Rheum. 2001;44(6):1351-8.

4. Kowal-Bielecka O, Fransen J, Avouac J, Becker M, Kulak A, Allanore Y, et al. Update of EULAR recommendations for the treatment of systemic sclerosis. Ann Rheum Dis. 2017;76(8):1327-39.

5. Tashkin DP, Roth MD, Clements PJ, Furst DE, Khanna D, Kleerup EC et al. Sclerodema Lung Study II Investigators. Mycophenolate mofetil versus oral cyclophosphamide in scleroderma-related interstitial lung disease (SLS II): a randomised controlled, double-blind, parallel group trial. Lancet Respir Med 2016:4:708-719.

6. Tashkin DP, Elashoff R, Clements PJ, Goldin J, Roth MD, Furst DE et al. Scleroderma Lung Study Research Group.Cyclophosphamide versus placebo in scleroderma lung disease. N Engl J Med 2006;354:2655-2666.

7. Sircar G, Goswami RP, Sircar D, Ghosh A, Ghosh P. Intravenous cyclophosphamide vs rituximab for the treatment of early diffuse scleroderma lung disease: open label, randomized, controlled trial. Rheumatology (Oxford). 2018;57(12):2106-13.

8. Daoussis D, Melissaropoulos K, Sakellaropoulos G, Antonopoulos I, Markatseli TE, Simopoulou T, et al. A multicenter, open-label, comparative study of Bcell depletion therapy with rituximab for systemic sclerosis-associated interstitial lung disease. Arthritis Rheum. 2017;46:625-31.

9. Khanna D, Lin CJF, Kuwana M, Allanore Y, Batalov A, Butrimiene I, et al. Efficacy and safety of tocilizumab for the treatment of systemic sclerosis: results from a phase 3 randomized controlled trial [abstract]. Arthritis Rheumatol. 2018;70(suppl 10) https://acrabstracts.org/abstract/efficacy-andsafety-of-tocilizumab-for-the-treatment-of-systemic-sclerosis-results-from-aphase-3-randomized-controlled-trial/. Accessed June 6, 2020.

10. Burt RK, Shah SJ, Dill K, Grant T, Gheorghiade M, Schroeder J, et al. Autologous non-myeloablativehaemopoietic stem-cell transplantation compared with pulse cyclophosphamide once per month for systemic sclerosis (ASSIST): an open-label, randomised phase 2 trial. Lancet. 2011;378: 498-506.

11. Van Laar JM, Farge D, Sont JK, Naraghi K, Marjanovic Z, Larghero J, et al. EBMT/EULAR Scleroderma Study Group. Autologous hematopoietic stem cell transplantation vs intravenous pulse cyclophosphamide in diffuse cutaneous systemic sclerosis: a randomized clinical trial. JAMA 2014;311: 2490-2498.

12. Sullivan KM, Goldmuntz EA, Keyes-Elstein L, McSweeney PA, Pinckney A, Welch B et al. SCOT Study Investigators.Myeloablative autologous stem-cell transplantation for severe scleroderma. N Engl J Med 2018;378:35-47.

13. Ayano M, Tsukamoto H, Mitoma H, Kimoto Y, Akahoshi M, Arinobu Y, et al. CD34-selected versus unmanipulated autologous haematopoietic stem cell transplantation in the treatment of severe systemic sclerosis: a post hoc analysis of a phase $1 / / /$ clinical trial conducted in Japan. Arthritis Res Ther. 2019;21(1):30.

14. Van den Hoogen F, Khanna D, Fransen J, Johnson SR, Baron M, Tyndall A, et al. 2013 classification criteria for systemic sclerosis: an American College of Rheumatology/European League against Rheumatism collaborative initiative. Arthritis Rheum. 2013;65:2737-47.

15. Kohno K, Nagafuji K, Tsukamoto H, Horiuchi T, Takase K, Aoki K, et al. Infectious complications in patients receiving autologous CD34-selected hematopoietic stem cell transplantation for severe autoimmune diseases. Transpl Infect Dis. 2009;11(4):318-23.

16. Frère $P$, Pereira $M$, Fillet $G$, Beguin $Y$. Infections after CD34-selected or unmanipulated autologous hematopoietic stem cell transplantation. Eur J Haematol. 2006;76(2):102-8.

17. Williams KM, Ahn KW, Chen M, Aljurf MD, Agwu AL, Chen AR, et al. The incidence, mortality and timing of Pneumocystis jiroveci pneumonia after hematopoietic cell transplantation: a CIBMTR analysis. Bone Marrow Transplant. 2016;51(4):573-80.

18. Messiaen PE, Cuyx S, Dejagere T, van der Hilst JC. The role of CD4 cell count as discriminatory measure to guide chemoprophylaxis against Pneumocystis 
jirovecii pneumonia in human immunodeficiency virus-negative immunocompromised patients: a systematic review. Transpl Infect Dis. 2017; 19(2). https://doi.org/10.1111/tid.12651. Epub 2017 Feb 15.

19. Henes J, Oliveira MC, Labopin M, Badoglio M, Scherer HU, Del Papa N, et al. Autologous stem cell transplantation for progressive systemic sclerosis: a prospective non-interventional study from the European Society for Blood and Marrow Transplantation Autoimmune Disease Working Party. Haematologica. 2020. https://doi.org/10.3324/haematol.2019.230128. Online ahead of print

20. Van der Kroef M, Van den Hoogen L, Mertens J, Blokland S, Haskett S, Devaprasad A, et al. Cytometry by time of flight identifies distinct signatures in patients with systemic sclerosis, systemic lupus erythematosus and Sjögrens syndrome. Eur J Immunol. 2020;50(1):119-29.

21. Lescoat A, Lecureur V, Roussel M, Sunnaram B, Ballerie A, Coiffier G. CD16positive circulating monocytes and fibrotic manifestations of systemic sclerosis. Clin Rheumatol. 2017;36(7):1649-54.

22. Gernert M, Tony HP, Schwaneck EC, Gadeholt O, Schmalzing M. Autologous hematopoietic stem cell transplantation in systemic sclerosis induces longlasting changes in B cell homeostasis toward an anti-inflammatory B cell cytokine pattern. Arthritis Res Ther. 2019;21(1):106.

23. Farge D, Henegar C, Carmagnat M, Daneshpouy M, Marjanovic Z, Rabian C, et al. Analysis of immune reconstitution after autologous bone marrow transplantation in systemic sclerosis. Arthritis Rheum. 2005;52(5):1555-63.

24. Alexander T, Thiel A, Rosen O, Massenkeil G, Sattler A, Kohler S, et al. Depletion of autoreactive immunologic memory followed by autologous hematopoietic stem cell transplantation in patients with refractory SLE induces long-term remission through de novo generation of a juvenile and tolerant immune system. Blood. 2009;113(1):214-23.

25. Karnell FG, Lin D, Motley S, Duhen T, Lim N, Campbell DJ, et al. Reconstitution of immune cell populations in multiple sclerosis patients after autologous stem cell transplantation. Clin Exp Immunol. 2017;189(3): 268-78.

26. Verburg RJ, Kruize AA, van den Hoogen FH, Fibbe WE, Petersen EJ, Preijers $F$, et al. High-dose chemotherapy and autologous hematopoietic stem cell transplantation in patients with rheumatoid arthritis: results of an open study to assess feasibility, safety, and efficacy. Arthritis Rheum. 2001;44(4): 754-60.

27. Guillaume T, Rubinstein DB, Symann M. Immune reconstitution and immunotherapy after autologous hematopoietic stem cell transplantation. Blood. 1998;92(5):1471-90.

28. Steingrimsdottir H, Gruber A, Björkholm M, Svensson A, Hansson M Immune reconstitution after autologous hematopoietic stem cell transplantation in relation to underlying disease, type of high-dose therapy and infectious complications. Haematologica. 2000;85(8):832-8.

29. Krautz C, Maier SL, Brunner M, Langheinrich M, Giamarellos-Bourboulis EJ, Gogos C, et al. Reduced circulating B cells and plasma lgM levels are associated with decreased survival in sepsis - a meta-analysis. J Crit Care. 2018:45:71-5

\section{Publisher's Note}

Springer Nature remains neutral with regard to jurisdictional claims in published maps and institutional affiliations.

Ready to submit your research? Choose BMC and benefit from:
- fast, convenient online submission
- thorough peer review by experienced researchers in your field
- rapid publication on acceptance
- support for research data, including large and complex data types
- gold Open Access which fosters wider collaboration and increased citations
- maximum visibility for your research: over 100M website views per year
At BMC, research is always in progress.
Learn more biomedcentral.com/submissions

